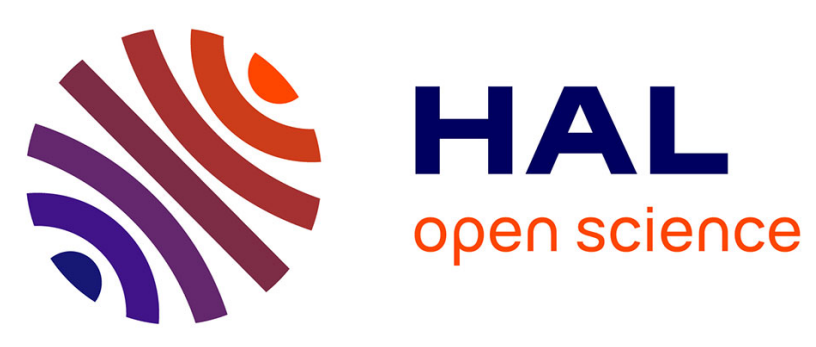

\title{
Railway Terminal Regulation
}

Nacima Baron

\section{To cite this version:}

Nacima Baron. Railway Terminal Regulation. Vickerman, Roger (eds.) International Encyclopedia of Transportation vol 5., pp.454 - 463, 2021. hal-03231277

\section{HAL Id: hal-03231277 \\ https://hal.science/hal-03231277}

Submitted on 20 May 2021

HAL is a multi-disciplinary open access archive for the deposit and dissemination of scientific research documents, whether they are published or not. The documents may come from teaching and research institutions in France or abroad, or from public or private research centers.
L'archive ouverte pluridisciplinaire HAL, est destinée au dépôt et à la diffusion de documents scientifiques de niveau recherche, publiés ou non, émanant des établissements d'enseignement et de recherche français ou étrangers, des laboratoires publics ou privés. 


\section{Provided for non-commercial research and educational use.}

Not for reproduction, distribution or commercial use.

This article was originally published in International Encyclopedia of Transportation (TRNS) published by Elsevier, and the attached copy is provided by Elsevier for the author's benefit and for the benefit of the author's institution, for non-commercial research and educational use, including without limitation, use in instruction at your institution, sending it to specific colleagues who you know, and providing a copy to your institution's administrator.

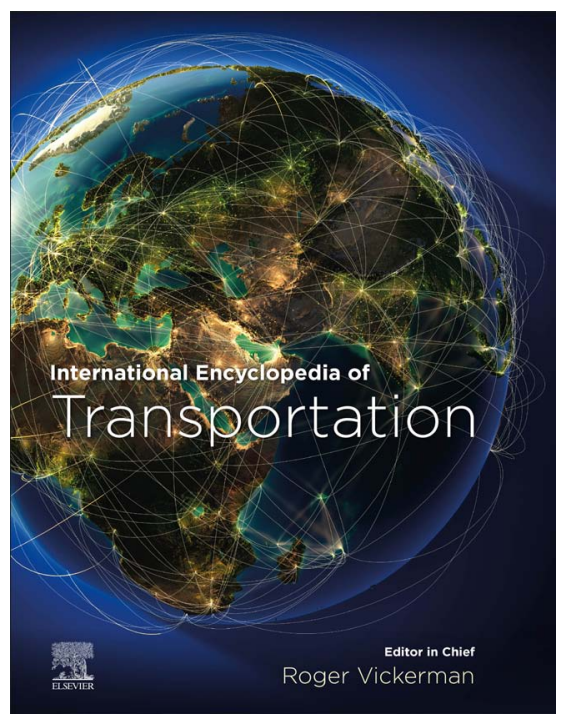

All other uses, reproduction and distribution, including without limitation, commercial reprints, selling or licensing copies or access, or posting on open internet sites, your personal or institution's website or repository, are prohibited. For exceptions, permission may be sought for such use through Elsevier's permissions site at:

https://www.elsevier.com/about/policies/copyright/permissions

Baron-yelles, Nacima. (2021) Railway terminal regulation. In: Vickerman, Roger (eds.) International Encyclopedia of Transportation. vol. 5, pp. 454-463. UK: Elsevier Ltd.

http://dx.doi.org/10.1016/B978-0-08-102671-7.10468-3

(C) 2021 Elsevier Ltd. All rights reserved. 


\section{Railway Terminal Regulation}

Nacima Baron, Université Paris Est, Laboratoire Ville Mobilité Transport - ENPC, France

(c) 2021 Elsevier Ltd. All rights reserved.

$\begin{array}{lr}\text { Terminal Regulation Definition and Scope } & 454 \\ \text { Railway Terminal Regulation Goals } & 454 \\ \text { Historical Background of Terminal Regulation } & 455 \\ \text { Railway Diversification Reframes Terminal Regulation } & 455 \\ \text { Railway Market Opening in Europe and its Consequences on Terminal Regulation } & 456 \\ \text { Railway Terminal Pricing Principles in Europe } & 457 \\ \text { Terminal Management Charging Models Across European Countries } & 457 \\ \text { Charging Patterns for Railway Terminal Use Across European Countries } & 460 \\ \text { Hot Topics and Future Trends in Terminal Regulation } & 460 \\ \text { Summary and Conclusions } & 462 \\ \text { Biography } & 462 \\ \text { References } & 462 \\ \text { Further Reading } & 463\end{array}$

\section{Terminal Regulation Definition and Scope}

Railway terminal regulation covers following areas:

- Physical management of terminal station (construction, maintenance, security, etc.);

- Definition terminal station access and exploitation, service pricing;

- Definition of legal status of owners and operators (state, collectivity, public, or private bodies);

- Competition rules between operators;

- Public service obligations (quantity, quality, and price of services delivered);

- Conflict prevention and solving;

- Price and access conditions to essential facilities and resources necessary for railway terminal activity (energy, land);

- Network interconnexion (technical compatibility, flow capacity).

In this broad perspective, terminal regulation is connected with railway terminal governance (who decides what), with railway terminal financing models (who pays for what), with railway terminal merchandising (how to locate railway terminal and how to manage them so as to attract passengers and clients and extract value). Railway terminal regulation also include technical regulation such as network regulation as well as security and safety norms appliance [A link to 10473: Rail network regulation can be done here], and is part of public transport regulation laws (international, national, metropolitan levels) when railway terminal is connected to intermodal nodes (buses, metro). When railway networks cross international borders, a bi- or multilateral regulation system can regulate the management of an international station and the right and duties of governments and railway companies.

This chapter is organized as follows: section "Railway Terminal Regulation Goals" introduces railway terminal regulation goals and section "Historical Background of Terminal Regulation" provides the historical background of terminal regulation. The section "Railway Diversification Reframes Terminal Regulation" explores the way terminal functional diversification goes along with a multiplication of stakeholders and a reframing of regulation conditions. Then section "Railway Market Opening in Europe and its Consequences on Terminal Regulation" details the specific but variegated conditions of terminal opening to market in European countries and section "Railway Terminal Pricing Principles in Europe" the zoning and pricing principles attached to terminal space and use. Sections "Terminal Management Charging Models Across European Countries" and "Charging Patterns for Railway Terminal Use Across European Countries" develop the terminal management charging models and their different patterns (the way terminal services are aggregated into blocks of activity across European countries), before reviewing hot topics and trends (section "Hot Topics and Future Trends in Terminal Regulation").

\section{Railway Terminal Regulation Goals}

Following cases, railway terminal can be either railway stations related to passenger travel, either cargo terminals interesting freight or depots, interesting both. All these terminals are part of network and provide services which exploitation may lead to scarcity of resources and overexploitation. For example, traffic caused by a busy railway crossing creates lack of capacity in a freight bottleneck. Hence railway terminals are essential facilities. Cargo terminals, marshalling yards, and train depots provide the infrastructure, building, and machines for flexible and efficient railway activity and maintenance (for the notion of efficiency, see Cantos and 
Maudos, 2001). Having access to a network of strategically located terminals with good connection to seaports, and offering modern rolling stock and good maintenance conditions help to reduce the time that vehicles are out of service and avoid empty trains. It secures and makes easier transshipment between rail and road or rail and sea or waterways and contribute to better flow management, which in turn leads to a reliable timetable.

Passenger railway stations are also essential facilities for transit and interurban transport. If railway activity is opened to market, stations turn into an essential facility. Railway undertakings need to have open information concerning the technical and financial conditions to access these stations, they must know how they can put a staff basis and what let services will be proposed to their final clients, the railway passengers. If railway activity is not opened to market, train flow regulation and passenger movement management are also very important to optimize the quality of railway service (train punctuality, comfort) [A link to the article 10014: Value of crowding in this Encyclopedia can be done here]. This needs also a sound regulation of the contractual relationships between station manager teams and train operator departments. Flow regulation is therefore necessary to assure fluidity in getting on and off a train, as well as to organize multimodal transport services from station to end destination. Terminal regulation is also needed in order to clarify the policy making conditions offered to nonrailway stakeholders (national governments, metropolitan governments, estate agents, data firms, etc.) in station development projects and to integrate side business activities such as shops, hotels, and other activities in stations (Dirhauge, 2013).

\section{Historical Background of Terminal Regulation}

Railway terminal regulation was necessary till the time railway lines were constructed. Even if it has changed a great deal since the 19th century, when train boomed in Europe and in the Americas, the fundamental question is still the capacity of envisioning a railway terminal as an essential facility. The genealogy of this notion is to be found the time when various companies were obliged to find agreements in order to share infrastructural nodes, platforms, depots, carbon storage, and water for steam machines. In 1911, a conflict aroused between competing American railroad companies (respectively the Wiggins Ferry Company, the Eads Railroad bridge terminal company, and the Merchant's bridge terminal company) that were converging at Saint Louis station, one of the largest railroad centers in the world at this time. Organizing the access of such competing railroads was not a basic thing. The solution proposed was that these three independent terminal systems merged into a single system owned by 14 independent railway companies, thereby completely controlling all interconnection facilities between both sides of the river Mississippi. According to the Supreme Court, mergers of terminals into one single system avoided unnecessary duplication of facilities. However, since not all railroad companies were owners of the terminal, the Sherman Act of 1912 did require nondiscriminatory access to the merged railroad terminals. Mandatory third-party access to complementary monopolistic infrastructure led to the birth of the crucial notion of essential facility (Dobbin, 2004) ([A link with article 10006: Natural monopoly in transport can be done here].

\section{Railway Diversification Reframes Terminal Regulation}

Most railway companies were nationalized before or after world war two in Europe, Asia, and in a majority of decolonizing countries, so terminal regulation changed a lot. Railway terminals turned to be driven by monopolistic companies and access to infrastructure was not so a problem, but large-scale railway programs (including high speed lines) were developed, along with railway modernization (e. g., line electrification). State or regional governments investments were needed for such great works. Rebuilding attractive stations and efficient terminals with public money was a part of this intent to foster rail development, seen as sustainable transport. So, terminal regulation was at this time included in the broader development of freight and passenger railway national regulation systems. Some terminals were specialized to serve port development or inland industrial plants, while urban terminals (including old depots and technical infrastructure) could be extended and redesigned into urban multifunctional programs (sometimes on an important scale). Railway terminal development schemes concerned progressively a broader array of stakeholders, including railway or metro companies, state administrations, public and private banks, municipal and metropolitan bodies, and industries. All these entities were eager to know precisely the conditions for intervening on railway land or the possibilities to buy pieces of land in terminals, and wanted to know the types of contracts (concessions, leasing, etc.), which could be signed with railway authorities for different kind of projects. Terminal regulation had to adapt and integrated new specifications. Depending on the countries, side businesses activities took place in terminal regulation schemes or were integrated in other type of regulation (land regulation, urban planning, etc.).

Japanese railway companies vertical separation and functional diversification occurred throughout the 1990s, after 1987 railway business act (which integrated «the construction of facilities around a station to promote connectivity with other transportation modes», quoted by Fumio 2018, p. 395) and then after 2005 Act on Enhancement of Convenience of Urban Railways. Terminals were located in the eastern metropolitan corridor and their urban environments were exposed to the steady rise of land values, hence the railway terminal premises, tracks, technical installations, and former passenger stations were converted into dense, high rise, intermodal, and multifunctional urban centers. Many Japanese companies engaged in a wide range of side businesses, such as land development, real estate development, department stores, and mobility services. Other project interested railway corridor at the peripheries of big cities [A link to 10454: Railway station (and network) planning and management article of the Encyclopedia can be done here]. Modest train station and old tracks could be turned into new transit-oriented development schemes integrating the reconstruction of a commuting railway line, a renovated commuting station and adjacent housing programs. Regulated benefits 
coming from train operation and unregulated side businesses deriving from other activities were the two dimensions of a new terminal regulation model. Each railway company was required to keep separate accounts for railway and other businesses and railway regulation was imposed only upon the railway side. Yet, according to economic cycles and to the long-term trajectory of megaprojects (in city centers) and miniprojects (in peripheral areas), railway activity, or side business activities could be more profitable, and the benefits taken from one activity could sustain the sustainability and long-term vision of the whole group.

\section{Railway Market Opening in Europe and its Consequences on Terminal Regulation}

"In theory, mixed-used developments around centrally located rail stations offer a perfect answer to the challenges of a futureoriented, post-peak oil sustainable development agenda focused on transit-accessible urban cores. In practice, however, the implementation of such megaprojects is highly complex, and costs and benefits are unevenly distributed." As Peters quote in 2012 (p. 163), Japanese terminal station megaprojects have been copied and globalized (Peters, 2009) The opening up to railway competition and the introduction of private capital in railway projects is of actuality worldwide, even in countries where a monopolistic company still dominates the national railway market. Technological companies, media and entertainment firms, real estate businesses, and hedge funds are newcomers in station (re)development projects or in railway infrastructure building or renovation. An example comes from China. Since 2014, the Chinese government launched a China railway development fund, scheduled to last for 15-20 years, with the aim of promoting private capital investments into rail projects through public-private partnerships (PPPs), in order to alleviate the debt carried by public authorities. In 2016, the Zhejiang government signed the first of such PPP agreements ( 34 years contract, the first four years of which for the construction, followed by 30 years of management) with the conglomerate Shanghai Fosun High Technology Group Co. Ltd. The project included land development around and above the eight new stations of the Hangzhou to Taizhou $269 \mathrm{~km}$ high speed line, which generated revenues could be used toward paying back railway development.

Russia and United States as well as in China and in European Union, which published, till the 1990s, various railway law packages encouraging railway market opening, historical railway companies rethink the place of terminals in their business model, and make proposition for adapting terminal regulation. Gómez-Ibáñez and De Rus (2006), and then Laurino et al. (2015) state that worldwide surveys are not numerous, the information very difficult to gather, and, moreover, both delineate with difficulty terminal economic regulation from overall railway regulation. Yet, a turning point seems to be attained. All these companies and incumbent railway undertakings understand that they have to add to the traditional tasks of terminal manager new expertises and skills, with new rules. Fig. 1 explains the value-oriented station regulation model, which associates traditional technical missions (passenger welcoming and train operation) with news targets such as passenger flow commercial fertilization and asset development. The basic

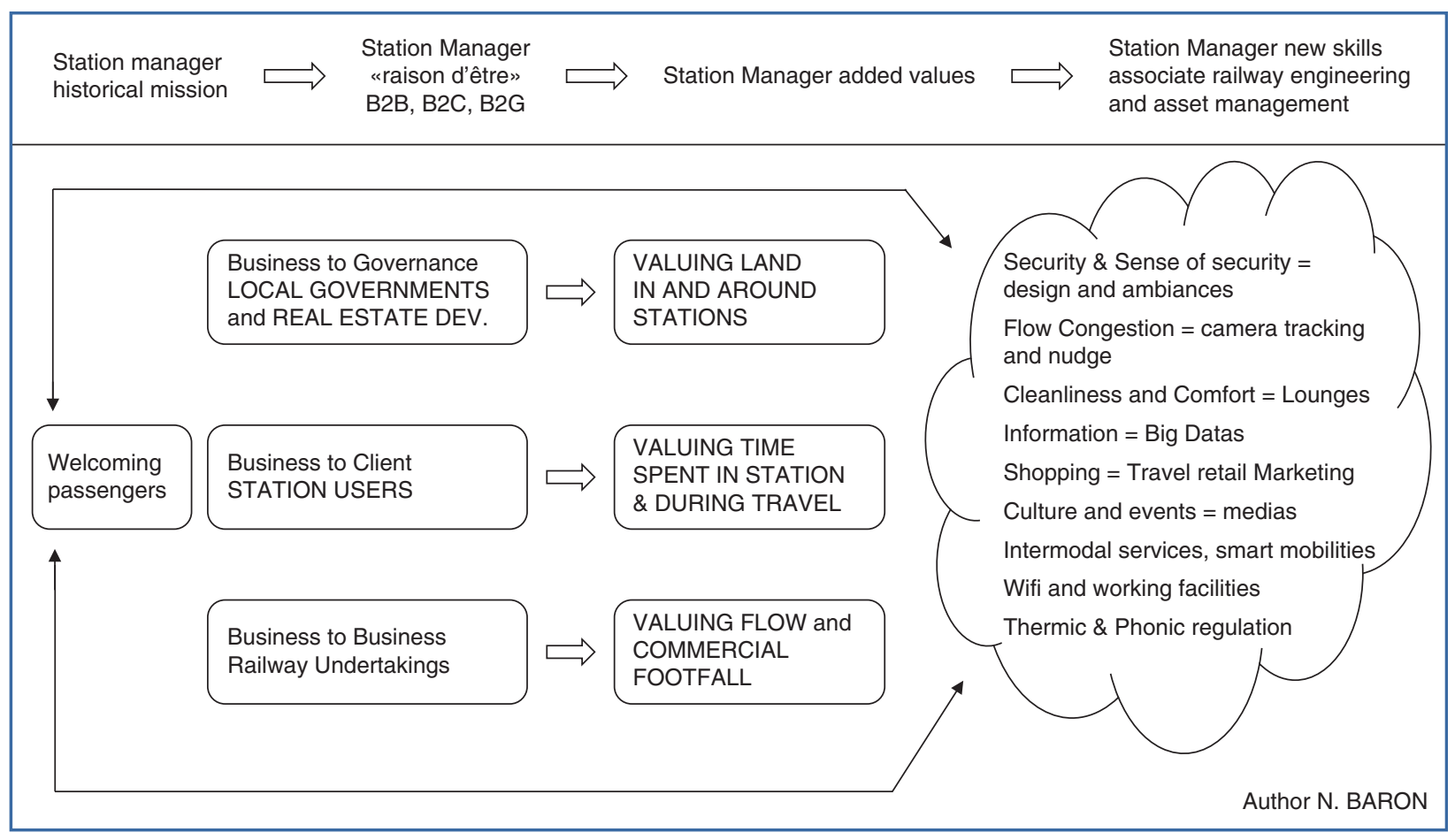

Figure 1 Value-oriented station regulation associate traditional technical missions (passenger welcoming and train operation) with news targets: flow fertilization and asset development. 
role of station management bodies is still related to the maintenance of the terminal buildings, its efficient management, its development in collaboration with the urban public authority, and transport systems. But, with liberalization trend, new challenges appear when they consider their strategic role being related to the maximization of three kinds of values: land value and long-term money return to be assured in shared programs signed with public authorities (in a business to governance perspective); flow value and careful asset management guaranteed with estate, retail and digital firms (in a business to business perspective); and time value, as an element of good travel experience of railway passengers (in a client oriented approach) (Beria et al., 2012). Such a commercial repositioning includes the redefinition of terminal station owner and manager legal duties and professional capacities. Providing comfort and security, assuring cleanliness and multilingual signage, offering first and last mile innovative mobility services as well as business lounges and WIFI network is now a must in main passenger stations and it changes regulation frames, especially in European countries.

\section{Railway Terminal Pricing Principles in Europe}

Terminal regulation is affected by many ways in the general context of the opening up to competition in the European Union. The main goal of EU railroad regulation is to increase competition on the railway markets by improving the independence of stakeholders, increasing the power of regulatory bodies and guaranteeing not only regulated access to monopolistic bottleneck components, but also regulating access to rail-related services, such as maintenance facilities, terminals, stations for freight and passenger trains (Finger and Messulam, 2015).

The introduction of fair and nondiscriminating access to passenger stations, maintenance depots, and cargo terminals is presented from the 1990s onward as a necessity in order to save railway industry, which is threatened by car transport for passenger as for freight competition. Vertical separation, autonomy, and neutrality are keywords. The autonomy and responsibilities of a station manager entity must be clearly delineated in the transformation or historical companies into vertically separated entities (infrastructure manager and railway undertaking). The station manager entity has to present service neutrality. The conditions of access and use have to be published and legally guaranteed by the independent Authority in order to avoid barriers to entry for newcomers in the market. Fig. 2 shows the terminal regulation system in European Union and how public stakeholders' interactions are reorganized.

The station manager must present price neutrality toward former monopolistic railway companies and incumbent undertakings for stations, depots, maintenance units, and freight terminals access and use. Terminal zoning and terminal access charges must be defined. This means that the stations and terminals are subject to a pricing process, and a value is assigned to the use of each element of a terminal [A link with 10016: Pricing Principles in the Transport Sector of this Encyclopedia can be done here]. The price of each elements and the final price is constructed from five elements:

- The terminal position on the rail network;

- The singular nature of the location and the scarcity and value of space (urban or industrial);

- The services available at the terminal (especially intermodal services, transshipment facilities);

- The environment and amenities around the terminal;

- The possibility of capturing large flows of passengers with varying abilities to pay (in the context of a passenger station).

The pricing of a terminal is based on regulatory engineering, but also generates discussion and dialogue, with differences of opinion between the players regarding the value they ascribe to the constraints that affect the station, so the independence of regulation authority is compulsory to stabilize the criteria and make consensus on the creation of price. The notion of "reasonable profit" is included in the main charging principles laid down in Directive 2012/34/EU in this quotation: "The charge imposed for track access within service facilities referred to in point 2 of Annex II, and the supply of services in such facilities, shall not exceed the cost of providing it, plus a reasonable profit." (Article 31.7.)(...) "Where services listed in points 3 and 4 of Annex II, as additional and ancillary services, are offered by only one supplier, the charge imposed for such a service shall not exceed the cost of providing it, plus a reasonable profit." (Article 31.8.). Reasonable profit means a rate of return on own capital that takes account of the risk taken by the terminal manager in the production of the facility or service, including that to revenue, or the absence of such risk, incurred by the operator of the service facility. Such return and is in line with the average rate for the sector concerned in recent years. An external rail regulator verifies the specifications for station access, defines the implementation of the safety measures, flow conditions, intermodal services and retail development possibilities. If several operators use a terminal, the rail regulator validates the access charging system and the station pricing schemes.

\section{Terminal Management Charging Models Across European Countries}

The idea of the terminal as a natural monopoly, separated from nonnatural monopoly components, is supposed to be applied in the European countries in a similar way, with the outcome being similar. In reality, the national interpretations vary substantially and these differences are deepened by the different starting point of the national rail companies (importance of historical background and national context). Two dimensions must be taken into account. 


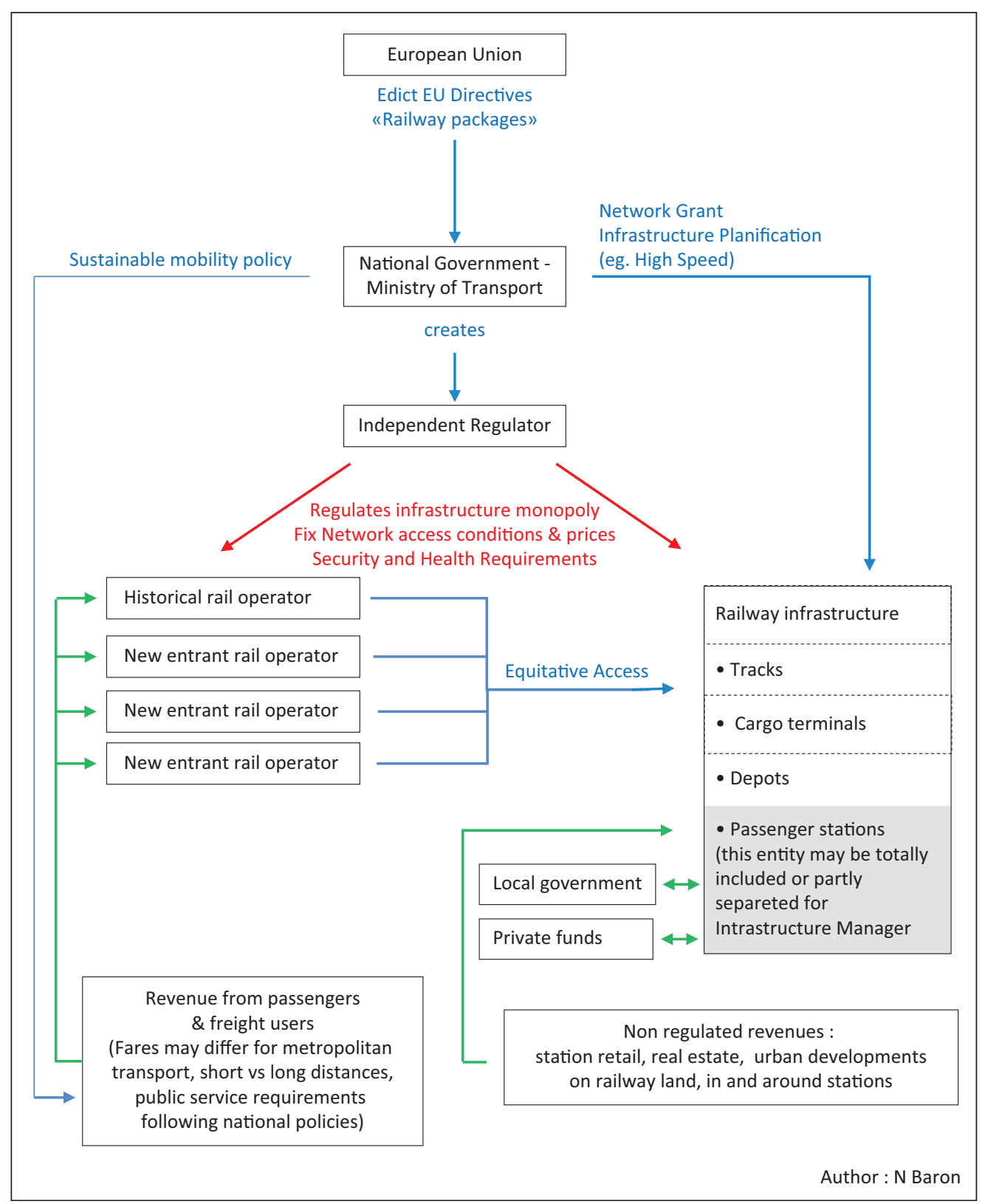

Figure 2 Terminal regulation system in European Union stakeholders interactions.

First, the way of separating railway premises ownership varies. In some countries, the ownership of depots and maintenance yards is of the incumbent, in other countries in the possession of the infrastructure manager. Thus, in Spain such facilities are not open to competitors and, in Italy, access of these facilities to competitors are subject to the incumbent's approval.

Second, the legal nature and the position of station manager entity in each national post market opening railway ecosystem differ a lot from one country to another. Table 1 offers an overview of European countries terminal regulation approach: the very heterogeneous importance of railway terminal infrastructure in number of stations and traffic activity, the existence or inexistence of a neutral entity in charge of railway terminal management, the types of charges and revenues (regulated and unregulated) that this entity manages (Teixeira et al., 2013). In Sweden, autonomy is as its maximum (Alexandersson and Rigas, 2013). Terminal ownership and management is carried out solely, by an independent company named Jernhusen, which is fully public owned (state and local governments are involved). The main task of Jernhusen is to manage land, technical and commercial assets as well as offices and housing buildings in the vicinity of terminals and stations. All other European countries include terminal management entities either as an element of the infrastructure manager, or, more rarely, in a department, a branch or a subsidiary with closer contact to former monopolistic train operator. In Germany, Deutsche Bahn Station\&Service AG is a legally independent holding company created during the reorganization of Deutsche Bahn. This is equivalent in Spain, where stations are conceived and operated 
Table 1 Overview of european countries terminal regulation approach : railway terminal infrastructure and activity, existence of a neutral entity in charge of railway terminal management, types of charges and revenues.

\begin{tabular}{|c|c|c|c|c|c|c|c|c|c|}
\hline & $\begin{array}{l}\text { Number } \\
\text { of } \\
\text { stations }\end{array}$ & $\begin{array}{l}\text { Number } \\
\text { of train } \\
\text { stops } \\
\text { (in Millions) }\end{array}$ & $\begin{array}{l}\text { Annual num- } \\
\text { ber of pas- } \\
\text { sengers } \\
\text { (in Millions) }\end{array}$ & $\begin{array}{l}\text { Entity responsible for the man- } \\
\text { agement of railway station }\end{array}$ & $\begin{array}{l}\text { Number of railway under- } \\
\text { takings using passenger } \\
\text { stations }\end{array}$ & $\begin{array}{l}\text { Station } \\
\text { segmentation }\end{array}$ & $\begin{array}{l}\text { Number of application charges } \\
\text { (main service package) and } \\
\text { modulations }\end{array}$ & $\begin{array}{l}\text { Publication or negotia- } \\
\text { tion } \\
\text { and regularity of tariff } \\
\text { renovation }\end{array}$ & $\begin{array}{l}\text { Unregulated } \\
\text { revenues (eg } \\
\text { retail) }\end{array}$ \\
\hline Austria & 1438 & 20 & 278 & Infrastructure Manager & Limited number & yes & 66 tariffs & Yearly published & Yes \\
\hline Belgium & 550 & & 225 & Incumbent railway undertaking & Limited number & no & 1 & Yearly published & Yes \\
\hline Bulgaria & 299 & & 24,6 & Infrastructure Manager & Single railway undertaking & & & & \\
\hline Croatia & 507 & & 18 & Infrastructure Manager & Single railway undertaking & yes & differs for each station & Yearly published & \\
\hline Finland & 192 & & 68,3 & & Single railway undertaking & & & Negotiated & \\
\hline France & 3029 & 40 & 1600 & $\begin{array}{l}\text { Incumbent railway undertaking } \\
\text { (holding) }\end{array}$ & $\begin{array}{l}\text { Limited number } \\
\text { (Thello \& Thalys) }\end{array}$ & yes & 173 tariffs $\times 9$ modulations & Yearly published & Yes \\
\hline Germany & 6547 & 152 & 2700 & Incumbent railway undertaking & $\begin{array}{l}\text { Multiple railway undertak- } \\
\text { ings (opened market) }\end{array}$ & yes & 196 tariffs $\times 2$ modulations & Yearly published & Yes \\
\hline Greece & 376 & & 7,4 & Infrastructure Manager & Limited number & yes & $\begin{array}{l}\text { included in te charges for the use } \\
\text { of infrastructure }\end{array}$ & Yearly published & \\
\hline Hungary & 1367 & 13,5 & 146 & Infrastructure Manager & Limited number & yes & $\begin{array}{l}4 \text { station segments } \times 2 \\
\text { modulations }\end{array}$ & Yearly published & \\
\hline Italy & 2260 & & 855 & $\begin{array}{l}\text { Infrastructure Manager for most } \\
\text { Stations + Grandi Stazioni }\end{array}$ & Limited number & no & $\begin{array}{l}\text { track access included in the station } \\
\text { charges for minimum access } \\
\text { package }\end{array}$ & & Yes \\
\hline Luxembourg & 68 & $1 ? 9$ & 21,5 & Infrastructure Manager & Single railway undertaking & no & 1 tariff + Extra fees for long trains & Yearly published & \\
\hline Norway & 336 & & & Infrastructure Manager & Limited number & no & $\begin{array}{l}2 \text { (one is zero, } 1 \text { for the city -airport } \\
\text { line) }\end{array}$ & Yearly published & Yes \\
\hline Poland & 2730 & 21 & 269 & Infrastructure Manager & $\begin{array}{l}\text { Multiple railway undertak- } \\
\text { ings (opened market) }\end{array}$ & yes & 15 tariffs & Yearly published & \\
\hline Slovenia & 273 & & 15,5 & Infrastructure manager & Single railway undertaking & yes & 4 tariffs & & \\
\hline Spain & 1939 & & 470 & Infrastructure manager & Limited number & yes & 3 tariffs $\times 4$ modulations & & Yes \\
\hline Sweden & 136 & & 205 & Specific entity Jernhusen & $\begin{array}{l}\text { Multiple railway undertak- } \\
\text { ings (opened market) }\end{array}$ & yes & 6 tariffs $\mathrm{x}$ modulations & & $\begin{array}{r}\text { Separated } \\
\text { account }\end{array}$ \\
\hline $\begin{array}{l}\text { United } \\
\text { Kingdom }\end{array}$ & 2537 & 89 & 1640 & $\begin{array}{l}\text { Infrastructure Manager in most } \\
\text { cases + specific entities rela- } \\
\text { tied to HS }\end{array}$ & $\begin{array}{l}\text { Multiple railway undertak- } \\
\text { ings (opened market) }\end{array}$ & yes & differ for each station & $\begin{array}{l}\text { Partly published and } \\
\text { partly negotiated } \\
\text { every } 5 \text { years }\end{array}$ & Yes \\
\hline
\end{tabular}


by infrastructure entity ADIF; as well as in Austria where ÖBB-Immobilienmanagement GmbH is 100\% owned by ÖBB-Infrastruktur AG; and in France, where passenger terminal management and development Gares\&Connexions, which was initially created as an autonomous holding within the historic company SNCF, is recently reintegrated to infrastructure manager SNCF Réseau.

The situation is on the opposite in Netherlands, where NS Stations is a specific body integrated in Dutch public owned train company NS; as it is in Switzerland, where stations are managed as part of CFF passenger department; as in Belgium, where SNCB has the control of stations buildings, platforms, car parks and retail. Italy and Great Britain presents specific cases, in the way that a horizontal division is created, that is to say that different kinds of stations obey to different regulation systems. In Italy (Arrigo and Di Foggia 2013), railway infrastructure manager RFI operates the great majority of stations, save the 14 biggest, under the responsibility of Grandi Stazioni, a body more oriented toward station asset management and opened to corporate groups and private funding. In Great Britain, only the main larger stations are managed and operated by the mainline Infrastructure manager, Network Rail, and the rest of stations are being a part of a franchise and managed by the franchised railway undertaking. High Speed stations are regulated apart. In the case of High Speed 1 line, Saint Pancras station and its five-star hotel were purchased and developed as a property asset in the context of the high-speed regulation system.

\section{Charging Patterns for Railway Terminal Use Across European Countries}

In most of European countries, the charging models obey to a common structure and are based on the principle of full cost. The methods used to set the charges are quite similar since the charging system aims at covering all the costs of the passenger station managers. But the situation is also very different from one country to another (IRG-Rail, 2015). To illustrate this, let us consider that the document Irish rail access charging system is a text of 12 pages where terminal access conditions take no more than three pages, whereas French "Document de référence des gares de voyageurs" has 66 pages. In few cases, such as Ireland, there is no specific charge for passenger stations since such charge is included in the charge for the use of infrastructure. In the other cases, the structure of charging systems is the following. In the majority of cases, a station manager develops a station segmentation using station characteristics and variables (passenger frequentation, traffic intensity, platforms number) and service characteristics. Moreover, according to the European norm, station charges are included into three possible categories: minimum access package fees, additional services, and ancillary services. The first group includes some criteria defining the infrastructure and some other elements describing the services provided in the station by station manager or by other providers. Among them, the use of common spaces and equipment (furniture, lifts, escalators, toilets); the reception, information, and orientation system (audio and display); the reception of persons with reduced mobility; other services such as heating, surveillance, lost \& found objects. The second group includes train parking facilities in adjacent depots, energy (preheating and precooling of trains) and water sources and maintenance facilities. Auxiliary or ancillary services refer to other services, such as access to information network, specific conditions for the announcement of trains, maintenance and inspection of vehicles, train dispatching services. Each criteria presence and weigh in the final pricing method is different from one country to another, and external charges (that is to say charges exterior to the three groups) are applied for the access and use of terminal premises (e.g., offices and desks, spaces for ticket sales, railway undertaking personnel) is applied in Austria, Bulgaria, France, Italy, and Luxembourg.

Table 2 shows railway station and terminal charging structure and most used criteria for pricing methods. Station tariff systems differ greatly. Some countries have tariff systems for line charges, but not for stations. Other countries have relatively simple systems (that is to say that stations are categorized by only few variables). However, some countries have built highly complex station pricing systems, whose structure depends on numerous variables. According to a 2015 UIC Study, 16 on the 27 European countries have some type of stations charges or auxiliary charges, 11 have only station charges, nine countries defines their station charges only by categorizing the stations by importance. Concerning the importance of station prices on the global price of access to network, the situation differs greatly between countries, types of network (for example, access to high speed station are much more expensive than access to conventional station) and between different pair of cities (origin-destination). France, Belgium, and Spain have the highest price levels (regularly between $8 \%$ and $15 \%$, sometimes $20 \%$ of total access price to network) and also the greatest difference between prices for small or medium sized station and prices for bigger stations. Concerning routes, the maximum stations charges observed account for $40 \%$ of total infrastructure charges, but remains as an exception.

\section{Hot Topics and Future Trends in Terminal Regulation}

The implementation of neutral access conditions and transparent charging systems remains a problem in many countries of Europe. Some of the convergence opportunities expected by Crozet in station charging did not occur (Crozet 2004). Tomeš and Jandovà (2018) have evaluated the international lines between Austria, Czech Republic, and Slovakia. They state that new entrants have caused major increases in train frequencies and cut prices. Yet, given the diverse pathways and levels of liberalization of rail activity in each country, significant problems remain. For example, when Austrian newcomer WESTbahn tried to access infrastructure and other essential facilities, it had difficulties in obtaining attractive timetable slots and its passengers could not easily use ticket selling facilities in terminals. «Further complaints included discriminatory path allocations and the exclusion of WESTbahn services from the timetable published by the incumbent» (p. 76). The construction of fees for using station and terminal facilities remains also very heterogeneous and continues to evolve as a consequence of the European Directives transposition slow rhythm in national laws. But 
Railway station and terminal charging structure and most used criterias in pricing methods

\begin{tabular}{|c|c|c|}
\hline & & Main Variables used in the pricing method \\
\hline \multirow[t]{2}{*}{$\begin{array}{l}\text { Station } \\
\text { segmentation }\end{array}$} & Station characteristics & $\begin{array}{l}\text { - Station category and size } \\
\text { - Train traffic } \\
\text { - Passenger traffic } \\
\text { - Platform number and size }\end{array}$ \\
\hline & Service characteristics & $\begin{array}{l}\text { - Service type, } \\
\text { - Stop type, } \\
\text { - Trip length } \\
\text { - Stopping type } \\
\text { - Peak vs off peak pricing }\end{array}$ \\
\hline \multirow[t]{2}{*}{$\begin{array}{l}\text { Minimum } \\
\text { access } \\
\text { package }\end{array}$} & $\begin{array}{l}\text { Station physical infra- } \\
\text { structure descriptors }\end{array}$ & $\begin{array}{l}\text { - Signage } \\
\text { - Information area } \\
\text { - Seating } \\
\text { - Loudspeaker } \\
\text { - Platform displays, } \\
\text { - Escalator, lift } \\
\text { - Security cameras } \\
\text { - Garbage bins, } \\
\text { - Trolley base } \\
\text { - Ticket machine + ticket gate } \\
\text { - Weather canopy } \\
\text { - Bike parking }\end{array}$ \\
\hline & $\begin{array}{l}\text { Minimum Proposed } \\
\text { Services }\end{array}$ & $\begin{array}{l}\text { - Cleaning service } \\
\text { - Security service } \\
\text { - Info point } \\
\text { - Announcement } \\
\text { - PRM service }\end{array}$ \\
\hline $\begin{array}{r}\text { Additional } \\
\text { Services }\end{array}$ & & $\begin{array}{l}\text { - Train parking facilities, } \\
\text { - Water, wastewater disposal } \\
\text { - Preheating /cooling facilities } \\
\text { - Maintenance facility }\end{array}$ \\
\hline $\begin{array}{r}\text { Auxiliary / } \\
\text { Ancillary } \\
\text { Services }\end{array}$ & & $\begin{array}{l}\text { - } \text { access to telecommunication networks } \\
\text { - provision of supplementary information (eg intermodal information) } \\
\text { - technical inspection of rolling stock } \\
\text { - Specific ticketing services (eg smart card, intermodal pass ...) } \\
\text { - Heavy maintenance }\end{array}$ \\
\hline
\end{tabular}

Source : EU Directives 2001 and 2012, IGRail, UIC

even if it is an uncertain and a long-term process, some trends can be observed. First, the "Europeanization" of stations is a strange process in the fact that adapting to the principles of competition leads simultaneously to the standardization of a general regulation pattern and to a specific situation in each country: that is one of the odd consequences of a long term movement of "europeanization of infrastructure" (Schipper 2011). Second, Beria et al. (2012) consider that terminal regulation (and in a broader approach of railway regulation) in biggest European countries (Germany, France, Spain, Italy) shows a balance between liberalization trends and a protectionist attitude from incumbent railways against liberalization, "with the states backing this behavior" (p. 110). The hypothesis is the same in Finger and Messulam, who consider that "the complexity of terminal access charges are not a market tool for pricing the use of rail infrastructures, but rather should be seen as public policy tools" (Finger and Messulam, 2015, p. 12). Third, if station management companies still play a dominant role as railway terminal infrastructure technical operators, but some of them consider to be as well service providers in vertically integrated structures and experts in travel retail and urban real estate. In this objective, some terminal management bodies progressively distinguish subdepartments (some with highly technological approach of flow management, some with a more strategic position of asset managers). These entities use all the possibilities of railway regulation to multiplicate and diversify the contractual relationships with other businesses, gradually evolving from a framework based on concessions (e.g., restaurant or hotel concessions) to another based on licenses, concessions, contracts, PPPs. Such terminal owners and/or managers consider their mission to be based not only on infrastructure providing, but on infrastructure plus service providing. Each national regulation system can limit or support this orientation. In some countries, unregulated 
revenues can either be completely excluded from the regulated charging system (when there is one, as in some European countries), or fully or partially taken into account.

An optimistic vision would state that, in Europe, the terminal manager has the capacity to sell services, to earn the revenues and to reinvest part of benefits in infrastructure projects, or in the train operating budgets, thus decreasing the price of train ticket and, as a final consequence, fostering train competitiveness. A pessimistic vision would consider that terminal managers specialization in service activities make them prefer managing big and rentable stations to small ones, thus threatening the integrity of network. Small stations and terminals may be less rentable but their openness may be considered as a public service obligation, and state or local governments have, in the European regulation system, few tools to support such policy. Station managers that are focused in priority on the production of economic results and are completely dissociated from other railway activities can also be invited to turn station into retail places and threaten overall railway sustainability, performance, and attractivity in the long term. Another unresolved issue concerns the way station manager will regulate themselves and/or follow overall regulation concerning big data production, openness, treatment, and commodification. These are crucial questions, giving the importance of good and passenger flows in railway terminals and the possible use of such information for a great quantity of service providers. Anyway, such transformations deeply change the governance and the nature of interactions between terminal entities, railway authorities and other stakeholders. The provision of terminal-bound services has shifted from being primarily a railway intraorganizational to an interorganizational task building on the idea of negotiation across a variety of economic sectors, among different levels of government, and between public and private actors, owners and contractors, consultants, and the end-users (consumers and passengers) themselves.

\section{Summary and Conclusions}

This chapter has presented an overview of terminal railway regulation principles and implementation. It has described the constitution of terminal infrastructure It has defined the concept of essential facility since its birth in 19th century US railway race to its regulatory implementation throughout the world, but especially in Japan, Europe and other Asian countries. The results and principal conclusions of the chapter are the following ones.

1. Terminal regulation transformations are caused by from two mains factors: (1) the transformative relationships between State, rail infrastructures, transport companies, and other stakeholders; and (2) the growing diversification of terminal functions, especially service, retail, land development, etc.

2. European institutions has framed specific regulation conditions and access conditions for terminals in the whole Union, but regulatory and pricing schemes remain different in the 27 countries analyzed.

3. Consequently, there is slow and heterogeneous pathways to free and indiscriminate access to terminals in Europe and only a few countries take the opportunity of their progressive autonomy from railway incumbents to develop side businesses in the context of regulated or in nonregulated railway models.

\section{Biography}

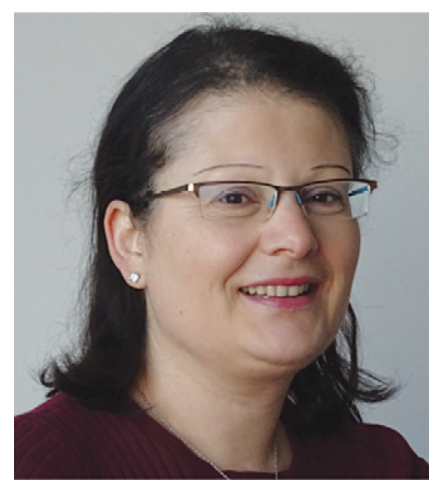

Nacima Baron holds a PhD in urban planning from Sorbonne University. She is full professor at Paris School of Urbanism at University Paris Est and also teaches transportation planning and urban projects at TU Delft and Rabat University. She holds a chair of railway station development and collaborates to various research projects on station retail, station and railway redevelopment schemes, and smart mobilities.

\section{References}

Alexandersson, G., Rigas, K., 2013. Rail liberalisation in Sweden. Policy development in a European context. Res. Transport. Bus. Manage. 6, 88-98.

Arrigo, U., Di Foggia, G., 2013. Competition and pricing of essential inputs: the case of access charges for the use of the Italian rail infrastructure. UTMS J. Econ. 4 (3), 295-307. Beria, P., Quinet, E., de Rus, G., Schulz, C., 2012. A comparison of rail liberalization levels across four European countries. Res. Transport. Econ. 36, 110-120.

Cantos, P., Maudos, J., 2001. Regulation and efficiency, the case of European railways. Transport. Res. A 35, 459-472.

Crozet, Y., 2004. European railway infrastructure: towards a convergence of infrastructure charging? Int. J. Transport Manage. 1, 5-15.

Dirhauge, H., 2013. Railway Policy-making: On Track? Palgrave Macmillan 239. 
Dobbin, F., 2004. How institutions create ideas: notions of public and private efficiency from early French and American railroading. L'année de la régulation 8, 15-50. Finger, M., Messulam, P., 2015. Rail Economics, Policy and Regulation in Europe. Edward Elgar 345.

Fumio, K., 2018. A study of vertical separation in Japanese passenger railways. Case Stud. Transport Policy 6(3), 391-399.

Gómez-Ibáñez, J., De Rus, G., 2006. Competition in the Railway Industry: An International Comparative AnalysisPL Cheltenham. Edward Elgar.

IRG-Rail, 2015. Overview on charging principles for passenger stations in Europe. Technical report, 15, 8, $23 \mathrm{p}$.

Laurino, A., Ramella, F., Beria, P., 2015. The economic regulation of railway networks: a worldwide survey. Transport. Res. A: Policy Pract. 77, 202-212.

Peters, D., 2009. The renaissance of inner-city rail station areas: a key element in contemporary urban restructuring dynamics. Crit. Plann. 16, 163-185.

Schipper, F., 2011. Infrastructural Europeanism, or the project of building Europe on infrastructures: an introduction. History Technol. 27 (3), 245-264.

Teixeira, P., Prodan, A., Lopes Pita, A., 2013. Railway Station and Auxiliary Charges in Europe. UIC, Paris, $30 \mathrm{p}$.

Tomeš, Z., Jandovà, M., 2018. Open access passenger rail services in Central Europe. Res. Transport. Econ. 72, 74-81.

\section{Further Reading}

ARAFER Autorité de régulation des activités ferroviaires et routières, 2017. Etude thématique sur la gestion des gares ferroviaires de voyageurs en France, $32 \mathrm{p}$. Gares\&Connexions SNCF Document de référence des gares de voyageurs pour l'horaire de service 20182019 2020, 66 p.

larnród Éirean//rish Rail, (s.d.) Access Charging System \& Performance Regime, 12 p. 